\title{
O OPERADOR \\ ASPECTUAL SE \\ NO ESPANHOL DO CHILE: \\ CONTEXTOS SEMÂNTICOS \\ E MORFOSSINTÁTICOS \\ DE USO
}

\section{EL OPERADOR ASPECTUAL SE EN EL ESPAÑOL DE CHILE: CONTEXTOS SEMÁNTICOS Y MORFOSINTÁCTICOS DE USO}

\author{
THE ASPECTUAL OPERATOR SE IN CHILEAN SPANISH: SEMANTIC AND \\ MORPHOSYNTACTIC CONTEXTS OF USE
}

Débora Cristina Paz Lourençoni*

Adriana Leitão Martins**

Universidade Federal do Rio de Janeiro

\begin{abstract}
RESUMO: Este trabalho enquadra-se no paradigma teórico do gerativismo por assumir que o traço aspectual de telicidade é representado na faculdade da linguagem e tem por objetivo investigar contextos semânticos e morfossintáticos que ensejem o uso do operador aspectual se na expressão desse traço no espanhol do Chile (EC). As hipóteses testadas são que, no EC, esse operador (i) aparece exclusivamente combinado a verbos de consumo e (ii) não aparece combinado à perífrase formada por "estar" (no presente) + gerúndio. Para tanto, aplicaram-se um teste de produção semiespontânea e um de julgamento de gramaticalidade comentado a cinco falantes nativos. Os resultados indicaram que esse operador parece (i) bastante produtivo com verbos de consumo, mas também associado a outros tipos de verbo, (ii) mais produtivo em sentenças cujo verbo tenha aspecto perfectivo e (iii) obrigatório com verbos inacusativos participantes da alternância causativa/incoativa quando utilizados em sua parte incoativa. As hipóteses foram refutadas.
\end{abstract}

PALAVRAS-CHAVE:Telicidade. Espanhol do Chile. Operador aspectual se.

RESUMEN: Este trabajo es parte del paradigma teórico del generativismo porque asume que el rasgo de telicidad (del inglés 'telicity' - evento con fin previsible) está representado en la facultad del lenguaje y tiene como objetivo investigar contextos semánticos y morfosintácticos que propicien el uso del operador aspectual "se" en la expresión de ese rasgo en el español de Chile (EC). Las hipótesis probadas son que, en el EC, ese operador (i) se combina exclusivamente con verbos de consumo y (ii) no se combina con "estar" (presente) + gerundio. Aplicamos un test de producción semiespontánea y uno de juicio de gramaticalidad comentado a

\footnotetext{
* Licenciada em Letras- Portugues/Espanhol, mestra e doutoranda em Linguística pela Universidade Federal do Rio de Janeiro(UFRJ).E-mail: debora.lourenconi@yahoo.com.br. 
cinco nativos. Los resultados indicaron que ese operador parece (i) muy productivo asociado a verbos de consumo pero también utilizado con otros tipos de verbo, (ii) más productivo en frases con verbos con aspecto perfectivo y (iii) obligatorio con verbos inacusativos participantes de la alternancia causativa/incoativa cuando se utiliza su parte incoativa. Las hipótesis fueron refutadas. PALABRAS CLAVE: Telicidad. Español de Chile. Operador aspectual "se".

ABSTRACT: This work is part of the theoretical paradigm of generative linguistics, since it assumes that the telicity aspectual feature is represented in the faculty of language, and it aims to investigate semantic and morphosyntactic contexts which may encourage the use of the aspectual operator se in the expression of this feature in Chilean Spanish (CS). The tested hypotheses are that, in CS, this operator (i) exclusively appears combined to consumption verbs and (ii) does not appear combined to "to be" (Simple Present) + gerund. We applied a semi-spontaneous production test and a commented grammaticality judgement test to five native speakers. Results showed that this operator seems (i)very productive with consumption verbs, although it is also associated with other types of verb, (ii) more productive with perfective aspect verbs and (iii)mandatory with causative/inchoative alternation unaccusative verbs, when used in their inchoative part.The hypotheses were refuted.

KEYWORDS: Telicity. Chilean Spanish. Aspectual operator se.

\section{INTRODUÇÃO}

Dentro do paradigma linguístico da gramática gerativa, a faculdade da linguagem é um módulo mental inato responsável específica e exclusivamente pela linguagem. Assumimos que os traços linguísticos presentes na faculdade da linguagem são universais e que tais traços podem ser realizados linguisticamente de diferentes maneiras. Neste trabalho, abordaremos, de maneira geral, o traço aspectual de telicidade.

O traço aspectual de telicidade tem relação com a finitude apresentada na descrição de um evento. Desse modo, eventos télicos possuem um ponto final definido para além do qual o evento não pode continuar e eventos atélicos não possuem um ponto final definido. Em algumas línguas naturais, é possível expressar linguisticamente o traço aspectual de telicidade por meio de um sintagma nominal determinado ${ }^{1}$, por meio de um sintagma preposicionado ou por meio de partículas delimitadoras - como a partícula up em inglês e a partícula se em espanhol.

Este trabalho aborda especificamente a partícula se como um marcador de telicidade no espanhol. Tal partícula é descrita na literatura como um operador aspectual cujo uso é opcional, podendo aparecer combinado a verbos transitivos e inacusativos associados necessariamente a um sintagma nominal determinado para indicar o ponto final definido de um evento.

Uma vez que parece haver na literatura informações divergentes sobre o uso desse operador aspectual se, o objetivo deste trabalho é investigar contextos semânticos e morfossintáticos que ensejem o uso do operador aspectual se na expressão do traço aspectual de telicidade no espanhol do Chile, examinando o caráter opcional dessa partícula. Ao investigar contextos semânticos e morfossintáticos que ensejem a presença do se aspectual em uma sentença, desejamos averiguar, respectivamente, o(s) tipo(s) semântico(s) dos verbos e a natureza temporal/aspectual dos verbos - no que diz respeito ao seu tipo semântico-aspectual e à sua morfologia - que podem se associar a essa partícula.

Neste trabalho, testamos as seguintes hipóteses, referentes ao uso do operador aspectual se no espanhol do Chile: (i) tal operador aparece exclusivamente combinado a verbos de consumo e (ii) tal operador não aparece combinado ao verbo "estar" no presente seguido de um verbo principal no gerúndio. A fim de alcançar o objetivo proposto, investigando as hipóteses delineadas, um teste de produção semiespontânea e um teste de julgamento de gramaticalidade comentado foram aplicados a falantes nativos do espanhol do Chile.

\footnotetext{
${ }^{1}$ Segundo De Miguel (1999), um sintagma nominal determinado (ou quantificado) é aquele que delimita um evento e marca o ponto final do intervalo no qual o evento ocorre. Em outras palavras, um sintagma nominal determinado é aquele que indica algo que pode ser exaustivamente contado ou medido, como o sintagma nominal "duas maçãs" no exemplo "João comeu duas maçãs".
} 


\section{O TRAÇO ASPECTUAL DE TELICIDADE E O OPERADOR ASPECTUAL SE}

A telicidade é a realização linguística aspectual de uma sentença que trata de uma situação que possui um ponto final expresso linguisticamente para além do qual essa situação não pode continuar. Segundo De Miguel (1999), no espanhol, a telicidade pode ser realizada linguisticamente por meio de três maneiras, a saber: por um sintagma nominal determinado - exemplo em (1) -, por uma partícula se combinada a um sintagma nominal determinado - exemplo em (2) - e por um sintagma preposicionado - exemplo em (3).

\section{(1) Sara ha fumado un puro.}

'Sara fumou um cigarro.'

(2) Sara se ha fumado un puro.

'Sara fumou um cigarro.'2

(3) Luis trabajaba hasta las tres.

'Luis trabalhava até as três.'

Neste trabalho, o objeto de estudo é a realização que contém a partícula se combinada a um sintagma nominal determinado para expressar a telicidade no espanhol do Chile. Uma vez que a telicidade é uma noção aspectual, tal partícula combinada a um sintagma nominal determinado é conhecida na literatura como um operador aspectual. Esse operador aspectual pode assumir, a depender da pessoa gramatical do sujeito ao qual se refere, as seguintes formas: me (primeira pessoa do singular), te (segunda pessoa do singular), nos (primeira pessoa do plural), os (segunda pessoa do plural) e se (terceira pessoa do singular e do plural) ${ }^{4}$.

De acordo com a gramática tradicional do espanhol (ALCINA; BLECUA, 1998; RAE, 2010), o operador aspectual se funciona como um reflexivo que tem um certo valor enfático, atuando como um complemento indireto em construções transitivas e podendo atuar também em construções intransitivas, indicando sempre uma intensificação da ação.

De acordo com a gramática descritiva do espanhol de De Miguel (1999), o operador aspectual se funciona como uma marca da delimitação de um evento. Para destacar essa delimitação, tal partícula aparece combinada a verbos transitivos e inacusativos que apareçam em contextos delimitados, os quais serão explicitados nos parágrafos a seguir.

No caso de verbos transitivos, o operador aspectual se só pode aparecer em eventos nos quais há um limite expresso, como na sentença em (4) abaixo. Quando não há um complemento - como na sentença em (5) - ou quando há um complemento sem determinação - como na sentença em (6) -, o uso do operador aspectual se é agramatical. Segundo De Miguel (1999), a presença do se aspectual na sentença em (4) não é obrigatória, ainda que seu uso pareça ser preferível.

(4) Juan (se) comió una tortilla él solo.

'João comeu uma tortilha sozinho.'

(5) Juan $\left({ }^{*}\right.$ se) come normalmente en este bar.

'João come normalmente neste bar.'

(6) Juan $\left({ }^{*}\right.$ se) come tortilla siempre que puede.

'João come tortilha sempre que pode.'

\footnotetext{
2 A sentença em (1) está com a mesma tradução da sentença em (2) porque a partícula se combinada a um sintagma nominal determinado para realizar linguisticamente a telicidade parece ser exclusiva da língua espanhola, não havendo, por isso, uma tradução equivalente no português do Brasil. ${ }^{3}$ Os exemplos em (1) e em (2) foram retirados de De Miguel (1999, p. 2986) e o exemplo em (3) foi retirado de De Miguel (1999, p. 3000). Os exemplos de (4) a (8) a
seguir foram retirados de De Miguel (1999, p. 2995-96).

${ }^{4}$ Neste trabalho, apesar das diferentes formas que pode assumir, com fins de simplificação, faremos referência a essa partícula apenas como "operador aspectual se" ou "se aspectual".
} 
No caso de verbos inacusativos, o operador aspectual se só pode aparecer em eventos nos quais haja uma menção implícita ou explícita ao início do evento e tal menção delimita esse evento. Comparemos as sentenças com o verbo "cair" em estrutura inacusativa nos exemplos em (7) e (8) a seguir.

\section{(7) El libro (se) ha caído del estante.}

'O livro caiu da prateleira.

(8) La lluvia ( ${ }^{*}$ se) cae.

'A chuva cai.'

No exemplo em (7), o sintagma preposicionado "del estante" marca o ponto de partida do evento descrito pelo verbo "cair" e a sentença pode ser interpretada como delimitada no seu início, sendo compatível com a presença do operador aspectual se na descrição desse evento. No exemplo em (8), de forma contrária, não há nenhum elemento na sentença que marque o ponto de partida do evento e a sentença não pode ser interpretada como delimitada, sendo a presença do se aspectual agramatical na descrição desse evento.

Em suma, de acordo com De Miguel (1999), o operador aspectual se veicula uma interpretação aspectual de que o evento apresenta um limite. Esse limite é final - no caso de sentenças com verbos transitivos - e inicial - no caso de sentenças com verbos inacusativos.

Além da visão da gramática tradicional e da gramática descritiva, há também diversos artigos que tratam do operador aspectual se. No que diz respeito especificamente ao tipo semântico dos verbos que podem se associar ao operador aspectual se, há autores que afirmam que somente verbos de consumo podem aparecer combinados a essa partícula (BABCOCK, 1970 apud LÓPEZ, 2002; SCHROTEN, 1972 apud LÓPEZ, 2002). Alguns exemplos de verbos de consumo seriam os verbos "comer", "beber" e "fumar", já que, segundo Castro e Moreno (2006), tais verbos têm um significado de aquisição ou de incorporação ${ }^{5}$. Para García e Pascual (2012), ainda, tais verbos selecionam um argumento incremental, o que significa dizer que o evento denotado pelo verbo afeta o objeto pouco a pouco, à medida que o evento progride (ROTHSTEIN, 2001).

No entanto, no texto de Sanz e Laka (2002), as autoras afirmam que a presença do operador aspectual seé um fenômeno totalmente produtivo na língua espanhola, não estando limitado a nenhum tipo semântico de verbo. Para indicar essa produtividade, Sanz e Laka (2002, p. 316) apresentam sentenças contendo o operador aspectual se combinado a verbos como "comer", "ler", "lavar", "regar", "cortar" e "cruzar".

Ao longo desta seção, observaremos exemplos fornecidos por diversos autores combinando o se aspectual com diferentes tipos semânticos de verbos, o que pode também ser entendido como um contra-argumento à proposta de que o operador aspectual se ocorre exclusivamente em sentenças que apresentem verbos de consumo.

Além dessa questão presente na literatura relacionada ao fato de o operador aspectual se aparecer exclusivamente associado a verbos de consumo, há autores que afirmam que o se aspectual só aparece em sentenças nas quais o término da ação já foi alcançado. Segundo De Miguel e Lagunilla (2000), o operador aspectual se é um clítico aspectual que mostra que uma ação alcançou o seu término.

Além disso, para De Miguel e Lagunilla (2000), a presença dessa partícula apresenta a ideia de que há um processo que culmina em uma mudança de estado ao final da ação. Para as autoras, a sentença em (9) abaixo é gramatical em espanhol porque traz uma leitura de mudança de estado - passar a saber a lição -, enquanto a sentença em (10) é agramatical pelo fato de o verbo "nascer" não pressupor um processo que culmina em uma mudança de estado, uma vez que é um verbo pontual.

\footnotetext{
${ }^{5}$ Devido a esse significado de aquisição ou incorporação, Arce Arenales (1989 apud LÓPEZ, 2002) chama esses verbos de incorporativos, já que, segundo ele, a ideia é que esses verbos possuem um significado de que o sujeito toma algo para si mesmo.
} 
(9) Me sé la lección. ${ }^{6}$

'Sei a lição.'

(10) ${ }^{*}$ El niño se nació sietemesino.

'O menino nasceu prematuro.'

Seguindo na mesma direção, López (2002) afirma que o operador aspectual se ocorre exclusivamente na expressão de situações nas quais o término da ação foi necessariamente alcançado. No entanto, diferentemente de De Miguel e Lagunilla (2000), a autora não menciona que deve haver necessariamente uma mudança de estado ao final do processo para que o operador aspectual se apareça na sentença.

Segundo López (2002), pelo fato de o operador aspectual se ocorrer exclusivamente na expressão de situações nas quais a ação alcançou o seu ponto final, a partícula em questão não se combina com o verbo "estar" no presente seguido de um verbo principal no gerúndio - exemplo em (11) - e também não se combina com expressões adverbiais durativas - exemplo em (12).

(11) ?Ahora mismo me estoy terminando el café $e^{8}$.

'Agora mesmo estou terminando o café.'

(12) ^Se comió la paella durante diez minutos.

'Comeu a paella durante dez minutos.'

Além de López (2002), Suárez Cepeda (2005) também parece acreditar que a presença do se aspectual na sentença mostre que o evento alcançou o seu ponto final. Segundo Suárez Cepeda (2005), apesar de o se ser uma partícula opcional, a leitura de uma sentença com a sua presença parece ser menos ambígua porque mostra que a situação alcançou o seu fim. Também de acordo com Preuss e Finger (2009), o se é um clítico operador aspectual delimitador cujo uso é opcional, uma vez que, segundo elas, aparece somente para destacar que o evento alcançou o seu ponto final.

Com base nessas afirmativas de De Miguel e Lagunilla (2000), Suárez Cepeda (2005) e Preuss e Finger (2009), mesmo que as autoras não mencionem especificamente, é possível inferir que elas - assim como afirma López (2002) - sugerem que, se a presença da partícula se traz para a sentença uma leitura de alcance do ponto final, o verbo "estar" no presente seguido de um verbo principal no gerúndio não se combina com o operador aspectual se.

Diante do quadro teórico apresentado nesta seção, neste trabalho, desejamos testar as seguintes hipóteses, referentes ao operador aspectual se no espanhol do Chile: (i) tal operador aparece exclusivamente combinado a verbos de consumo (BABCOCK, 1970 apud LÓPEZ, 2002; SCHROTEN, 1972 apud LÓPEZ, 2002) e (ii) tal operador não aparece combinado ao verbo "estar" no presente seguido de um verbo principal no gerúndio (DE MIGUEL; LAGUNILLA, 2000; LÓPEZ, 2002; SUÁREZ CEPEDA, 2005; PREUSS; FINGER, 2009). Tais hipóteses serão colocadas à prova por meio dos dados obtidos pela aplicação dos testes explicitados na seção a seguir deste artigo.

\footnotetext{
${ }^{6}$ Destacamos que, conforme apresentado no segundo parágrafo desta seção, o operador aspectual se pode assumir outras formas, a depender da pessoa gramatical do sujeito. No exemplo em (9), esse operador assume a forma me por concordar com o sujeito nulo de primeira pessoa do singular.

${ }^{7}$ O exemplo em (9) foi retirado de De Miguel e Lagunilla (2000, p. 28) e o exemplo em (10) foi retirado de De Miguel e Lagunilla (2000, p. 24).

${ }^{8}$ Este é mais um exemplo em que o operador aspectual se assume uma forma diferente em função da pessoa gramatical do sujeito com o qual concorda. Ainda a respeito do exemplo em (11), vale destacar que, apesar de López (2002) dizer que o operador aspectual se é incompatível com um presente que denote ação em curso (LÓPEZ, 2002, p. 112), a autora utiliza a interrogação no início da sentença, ao invés de usar o asterisco, para indicar essa incompatibilidade. Já nos outros exemplos nos quais a autora menciona uma incompatibilidade, ela utiliza o asterisco. Talvez o uso da interrogação no exemplo destacado mostre que a autora não quer ser tão categórica a respeito dessa incompatibilidade.

${ }^{9}$ Os exemplos em (11) e (12) foram retirados de López (2002, p. 112).
} 


\section{METODOLOGIA}

\subsection{TESTE DE PRODUÇÃO SEMIESPONTÂNEA}

O teste de produção semiespontânea, desenvolvido por Martins, Lourençoni e Novaes (2013), era composto por treze conjuntos de fotos, as quais deveriam ser descritas pelos participantes, sendo o primeiro conjunto utilizado apenas como uma prática, a fim de garantir que os informantes haviam entendido a tarefa a ser desenvolvida. Essa prática era realizada pelos próprios informantes, havendo interferência dos pesquisadores apenas quando o comando não lhes parecia ter ficado claro.

A tarefa solicitada era que os informantes narrassem cada conjunto, sendo necessário que eles falassem de cada uma das fotos presentes em cada um dos conjuntos. Após a prática, os outros doze conjuntos eram apresentados um a um. A fim de não influenciar a produção dos informantes, era feita a ressalva de que eles tentassem não se preocupar com o fato de o espanhol não ser a língua nativa dos pesquisadores.

Em cada conjunto, havia três fotos e cada foto retratava uma etapa de uma situação. A primeira foto sempre apresentava uma ação começando a ser desenvolvida, a segunda foto, uma ação em andamento e a terceira foto, uma ação já concluída. Além disso, todos os objetos sobre os quais as ações recaíam eram objetos de caráter delimitado, o que possibilitaria a expressão linguística do traço aspectual de telicidade. Para uma melhor visualização, considere-se a figura abaixo, a qual retrata o conjunto de fotos que representa a ação de "fritar um ovo"10.

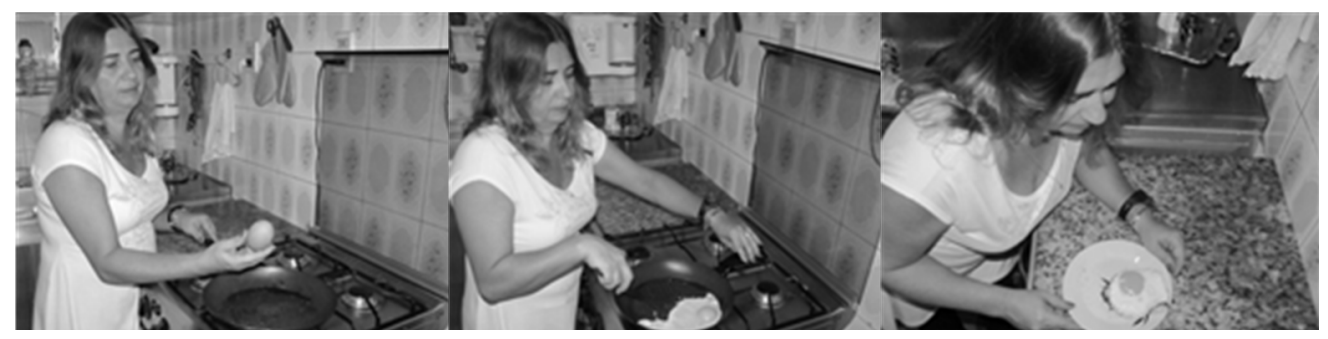

Figura 1: Fotos do conjunto que representa a ação de "fritar um ovo".

Fonte: Martins, Lourençoni e Novaes (2013, p. 267).

Com esse teste, esperávamos testar a hipótese (i) - segundo a qual o operador aspectual se aparece exclusivamente combinado a verbos de consumo no espanhol do Chile - através dos conjuntos de fotos cujas ações retratadas deveriam ser descritas por meio de verbos que não fossem considerados verbos de consumo (como, por exemplo, os conjuntos "pintar um quadro" e "recortar um desenho"). Além disso, esperávamos testar a hipótese (ii) - segundo a qual o operador aspectual se não aparece combinado ao verbo "estar" no presente seguido de um verbo principal no gerúndio no espanhol do Chile - através da segunda foto dos conjuntos de fotos, que retratava sempre uma ação em andamento, uma vez que a morfologia mais prototípica para expressar uma ação dessa natureza, ao menos no português do Brasil, é o "estar" no presente seguido de um verbo principal no gerúndio (MARTINS; LOURENÇONI; NOVAES, 2013).

No entanto, é importante ressaltar que não havíamos como garantir que essas hipóteses seriam de fato colocadas à prova pelo fato de o operador aspectual se ser uma partícula cujo uso é opcional e pelo fato de esse teste ser de produção. Sendo assim, os informantes poderiam produzir as sentenças da maneira que achassem melhor e, consequentemente, poderiam optar por não utilizar o se aspectual em suas produções.

\footnotetext{
${ }^{10}$ Além do conjunto de fotos que retrata a ação de fritar um ovo, os outros onze conjuntos retratavam as seguintes ações: comer uma banana, fazer uma limonada, ralar uma cenoura, descascar uma laranja, fazer um chá, preparar um hambúrguer, abrir um coco, pintar um quadro, recortar um desenho, escrever um texto e beber um copo de refrigerante. $\mathrm{O}$ conjunto de fotos apresentado aos informantes apenas como uma prática da tarefa retratava a ação de montar um quebra-cabeça.
} 
Quanto à análise feita em relação às sentenças produzidas nesse teste, uma vez que o objetivo deste trabalho é investigar contextos semânticos e morfossintáticos que ensejem o uso do operador aspectual se, optamos por analisar as sentenças télicas produzidas levando em consideração o tipo de verbo e a morfologia verbal presentes nas sentenças. Quanto ao tipo de verbo, optamos por fazer essa análise com o objetivo de tentar investigar se é possível associar ou não o se aspectual a algum tipo semântico-aspectual de verbo, além de investigar se a sua produção acontece exclusivamente associada aos verbos de consumo. Quanto à morfologia, optamos por fazer essa análise com o objetivo de tentar investigar se é possível associar ou não o se aspectual a uma determinada morfologia, além de investigar se é agramatical a sua combinação com o verbo "estar" no presente seguido de um verbo principal no gerúndio.

\subsection{TESTE DE JULGAMENTO DE GRAMATICALIDADE COMENTADO}

O teste de julgamento de gramaticalidade comentado era composto por vinte e quatro sentenças construídas a partir da seleção de doze verbos $^{11}$, que apareciam duas vezes cada. Apenas a metade das sentenças continha o operador aspectual se, sendo que o mesmo verbo aparecia ora combinado a ele, ora não. Além disso, o verbo repetido nas duas sentenças apresentava sempre a mesma morfologia verbal.

As tarefas solicitadas aos informantes eram que eles julgassem as sentenças como naturais ou estranhas e, caso julgassem alguma sentença como estranha, que a modificasse de modo que a tornasse o mais natural possível. Era ressaltado pelo pesquisador que os informantes poderiam alterar qualquer constituinte presente na sentença que eles julgassem como estranho. Logo, não estava restrita a possibilidade de modificação apenas à morfologia verbal ou à presença/ausência do operador aspectual se, por exemplo.

Além da presença/ausência do se aspectual, as outras variáveis controladas nesse teste foram o tipo de verbo e a morfologia verbal utilizados nas sentenças, tal como será explicitado nos dois parágrafos a seguir.

Em relação ao tipo de verbo, foram utilizadas oito sentenças com verbos de estado, oito sentenças com verbos de processo culminado e oito sentenças com verbos de culminação ${ }^{12}$. Das oito sentenças utilizadas com cada um dos tipos de verbo citados, quatro apareciam com o operador aspectual se e quatro sem esse operador aspectual.

Em relação à morfologia verbal, foram utilizadas seis sentenças com a morfologia de pretérito perfeito simples, seis sentenças com a morfologia de pretérito perfeito composto, seis sentenças com o verbo "estar" no presente seguido de um verbo principal no gerúndio e seis sentenças com o verbo no infinitivo. Das seis sentenças utilizadas com cada uma das morfologias verbais citadas, três apareciam combinadas ao operador aspectual se e três sem esse operador aspectual.

Com esse teste, esperávamos testar a hipótese (i) - segundo a qual o operador aspectual se aparece exclusivamente combinado a verbos de consumo no espanhol do Chile - através das sentenças nas quais figurava um verbo que não fosse classificado como um verbo de consumo (como, por exemplo, os verbos "entender" e "abrir"). Tal hipótese seria refutada se os informantes julgassem as sentenças com esses verbos associados ao operador aspectual se categoricamente como naturais ou, ainda, se os informantes incluíssem o se aspectual em sentenças com esses verbos.

Além disso, esperávamos testar a hipótese (ii) - segundo a qual o operador aspectual se não aparece combinado à perífrase formada pelo verbo "estar" no presente seguido de um verbo principal no gerúndio no espanhol do Chile - através das sentenças constituídas pela perífrase da qual trata a hipótese. Tal hipótese seria refutada se os informantes julgassem as sentenças com essa morfologia

\footnotetext{
${ }^{11}$ Os doze verbos selecionados foram: abrir, acabar, caer (cair), comer, entender, cerrar (fechar), gustar (gostar), mirar (olhar), partir, querer, rallar (ralar) e tomar.

${ }^{12}$ Essa divisão de tipos de verbo é baseada em Vendler (1967). Segundo o autor, os verbos podem ser divididos em quatro tipos, a depender da semântica do predicado verbal. Os quatro tipos são: (i) estados, que são verbos que não apresentam dinamicidade, como, por exemplo, "amar"; (ii) atividades, que são verbos que apresentam dinamicidade e não possuem um ponto final determinado, como, por exemplo, "correr"; (iii) processos culminados, que são verbos que apresentam dinamicidade e possuem um ponto final determinado, como, por exemplo, "correr uma maratona"; e (iv) culminações, que são verbos pontuais, como, por exemplo, "entrar". É válido ressaltar que, apesar de a classificação de tipos de verbo de Vendler (1967) apresentar quatro tipos, não foram utilizadas sentenças com verbos de atividade no teste pelo fato de esse tipo de verbo não apresentar argumento interno e, por isso, não poder ser considerado télico e, consequentemente, não poder aparecer combinado ao operador aspectual se.
} 
associada ao operador aspectual se categoricamente como naturais ou, ainda, se os informantes acrescentassem o se aspectual em sentenças com essa morfologia.

Uma vez que o objetivo deste trabalho é investigar contextos semânticos e morfossintáticos que ensejem o uso do operador aspectual se, no desenvolvimento do teste, optamos por utilizar outros tipos de verbo, além de verbos cujo tipo semântico fosse de consumo, e outras morfologias, além do verbo "estar" no presente seguido de um verbo principal no gerúndio. Tal opção foi motivada pelas mesmas razões apontadas ao final da seção anterior sobre os critérios de análise das sentenças produzidas no teste de produção semiespontânea.

As sentenças em (13) a seguir ilustram o verbo de estado "entender" combinado à morfologia de pretérito perfeito simples, aparecendo em (13a) com a presença da partícula se e em (13b) sem a presença da partícula se - tais exemplos constituem sentenças que talvez nos possibilitassem refutar a hipótese (i). As sentenças em (14) a seguir ilustram o verbo de culminação "abrir" com o verbo "estar" no presente seguido de um verbo principal no gerúndio, aparecendo em (14a) com a presença da partícula see em (14b) sem a presença da partícula se - tais exemplos constituem sentenças que talvez nos possibilitassem refutar as hipóteses (i) e (ii).

(13) a. Miguel estudió mucho y se entendió todo el contenido.

'Miguel estudou muito e entendeu todo o conteúdo.'

b. Eduardo entendió el plan.

'Eduardo entendeu o plano.'

(14) a. Hace calor y Sebastián se está abriendo las dos ventanas por completo.

'Está calor e Sebastião está abrindo as duas janelas por completo.'

b. Francisco está abriendo la puerta.

'Francisco está abrindo a porta.'

\subsection{PARTICIPANTES E PROCEDIMENTOS}

Foram selecionados cinco informantes falantes nativos do espanhol do Chile. Todos possuíam faixa etária entre dezenove e trinta e dois anos e variavam o nível de escolaridade entre ensino médio completo e ensino superior completo. Dos cinco informantes, dois eram mulheres e três eram homens e, quanto à escolaridade, dois possuíam ensino médio completo, um possuía ensino superior incompleto e outros dois possuíam ensino superior completo.

Os testes foram aplicados pelo programa skype, que dispõe de chamadas de vídeo online. Os participantes recebiam primeiro o teste de produção semiespontânea e, após finalizá-lo, recebiam o teste de julgamento de gramaticalidade comentado. À medida que os informantes realizavam as tarefas solicitadas, as suas respostas eram gravadas por meio de um gravador de áudio e, posteriormente, foram transcritas antes de serem analisadas.

Dos cinco participantes, três fizeram as duas tarefas uma seguida da outra pelo skype; um informante fez o teste de produção semiespontânea em um dia e, em outro, fez o teste de julgamento de gramaticalidade comentado, ambos pelo skype; e um outro informante fez o teste de produção semiespontânea pelo skype em um dia e o teste de julgamento de gramaticalidade comentado em outro e de maneira escrita, por e-mail.

\section{RESULTADOS}

\subsection{TESTE DE PRODUÇÃO SEMIESPONTÂNEA}

Por se tratar de um teste de produção semiespontânea, não havíamos como garantir que os informantes produziriam sentenças com a presença do operador aspectual se, já que ele é uma partícula opcional, como descrito na literatura e abordado na segunda seção deste artigo.

Lourençoni \& Martins | O operador aspectual se no espanholdo Chile: contextos.. 
Dessa forma, foram analisadas todas as sentenças télicas em que figurava como complemento verbal um sintagma nominal determinado, realizado ou não foneticamente, com ou sem o operador aspectual $s e$, produzidas pelos cinco informantes ${ }^{13}$. Ao descrever as fotos dos doze conjuntos de fotos pertencentes a esse teste, os participantes produziram 133 sentenças que podem ser consideradas télicas.

Na expressão do traço aspectual de telicidade, das sentenças télicas produzidas pelos informantes, 12 sentenças foram realizadas por meio do operador aspectual se combinado a um sintagma nominal determinado. Sendo assim, em número percentual, 9\% das sentenças télicas produzidas apresentavam o operador aspectual se. Dos cinco informantes submetidos ao teste, um deles não produziu nenhuma sentença com o $s e$ aspectual e os outros quatro produziram entre uma e cinco sentenças contendo a partícula se na expressão do traço aspectual de telicidade.

Dentre os verbos que apareceram combinados ao operador aspectual se na fala dos participantes, estão os verbos "acabar", "comer", "exprimir" (espremer), "partir" e "tomar". As sentenças de (15) a (26) a seguir apresentam as doze produções com o operador aspectual se dos cinco informantes que participaram do teste ${ }^{14}$.

(15) "y la última imagen ya se acabó la bebida."

'e na última imagem já acabou a bebida.'

(16) "y en la tercera imagen el coco ya preparado [para comérselo]."

'e na terceira imagem o coco já preparado para comê-lo'.

(17) "y después lo pone en un plato [para comerse el huevo frito]."

'e depois o põe em um prato para comer o ovo frito.'

(18) "sale la persona con el plátano ya pelado [y empezando a comérselo]."

'está a pessoa com a banana descascada e começando a comê-la.'

(19) "y en la tercera foto ya se comió todo el plátano."

'e na terceira foto já comeu toda a banana.

(20) "y se comió el plátano."

'e comeu toda a banana.'

(21) "la segunda foto la mujer abrió el plátano [y se lo está empezando a comer ${ }^{15}$."

'na segunda foto a mulher abriu a banana e está começando a comê-la.'

(22) "en la segunda foto la señora se está exprimiendo los limones."

'na segunda foto a senhora está espremendo os limões.'

(23) "está partiendo con el cuchillo gigante la fruta verde [y después se la partió]."

'está partindo com a faca gigante a fruta verde e depois a partiu.'

(24) "comienza a tomar coca cola con mucha sed [y después se tomó todo el vaso]."

'começa a tomar coca-cola com muita sede y depois tomou todo o copo.'

(25) "y en la tercera ya se tomó (un vaso con coca cola)."

'na terceira já tomou (um copo de coca-cola).'

(26) "se tomó el té".

'tomou o chá.'

\footnotetext{
${ }^{13}$ Incluímos na análise inclusive sentenças com verbos de estado, considerando-se que autores como Nishida (1994) indicam que mesmo esses verbos podem se combinar ao operador aspectual se em sentenças télicas. Por outro lado, excluímos da análise tanto sentenças produzidas pelos informantes que fossem comentários e não descrições das ações desempenhadas pela personagem nas fotos (como em "no sé cómo se habla") quanto sentenças télicas que tivessem um se reflexivo, devido ao fato de esse tipo de se assumir uma outra função na sentença diferente daquela assumida pelo operador aspectual se.

${ }^{14}$ Em alguns exemplos, a oração anterior foi inserida para esclarecer o contexto. Nos exemplos em que aparece mais de uma oração, as orações consideradas na análise foram somente as que estão destacadas entre colchetes.

${ }^{15}$ Consideramos, neste caso, o complemento lo e a partícula se ligados ao verbo comer
} 
Das produções listadas acima, os exemplos de (16) a (21), com o verbo "comer", e de (24) a (26), com o verbo "tomar", apresentam verbos que podem ser caracterizados como verbos de consumo, já que ambos veiculam a ideia de que o sujeito toma algo para si mesmo, tendo, assim,um significado de aquisição ou de incorporação (CASTRO; MORENO, 2006; GARCÍA; PASCUAL, 2012), tal como apresentado na seção 2 deste artigo. Os outros verbos que apareceram combinados ao se aspectual na produção dos informantes - "acabar", "exprimir" (espremer) e "partir" - não podem ser caracterizados como verbos de consumo. O gráfico 1 a seguir apresenta os verbos de consumo em oposição aos demais verbos nas sentenças télicas com e sem o operador aspectual se produzidos por todos os informantes nesse teste ${ }^{16}$.

Gráfico 1: Verbos de consumo versus demais verbos utilizados na produção de sentenças télicas do teste de produção semiespontânea.

Teste de produção semiespontânea: verbos de consumo versus demais verbos

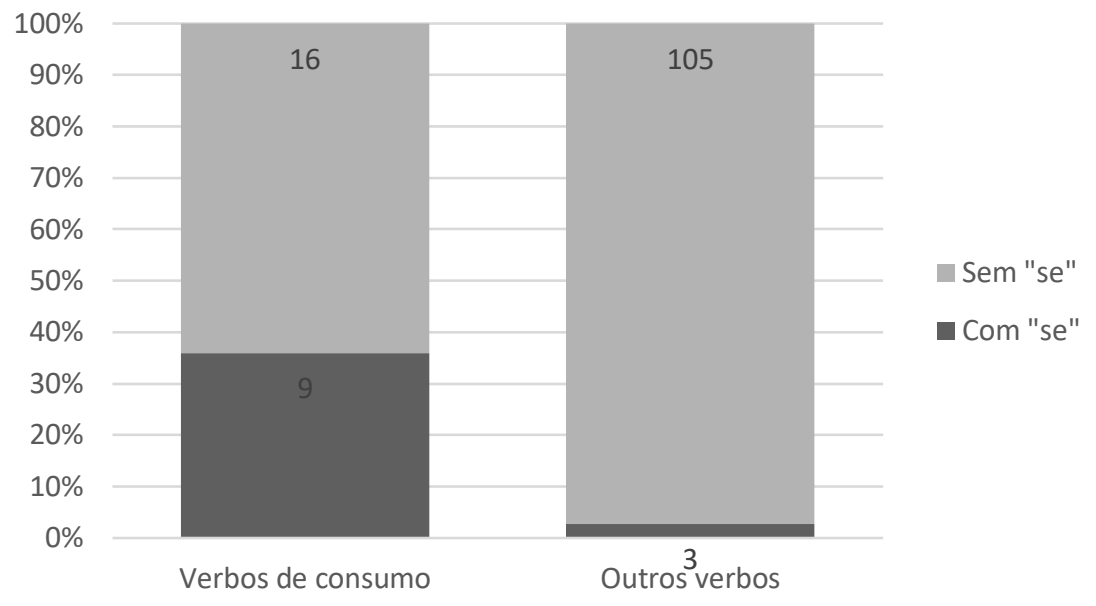

Como demonstra o gráfico 1, os verbos de consumo foram combinados ao operador aspectual se em 9 ocorrências, o que corresponde a 36\% das produções destes verbos. Verbos que não eram de consumo, por sua vez, foram combinados ao operador aspectual se em 3 ocorrências, o que corresponde a 2,8\% das produções destes verbos. Tal quadro demonstra que a ocorrência do se aspectual foi mais produtiva com verbos de consumo. Ainda a respeito destes verbos, vale destacar que as 16 ocorrências de verbos de consumo em sentenças télicas desassociados do se aspectual foram com os verbos "comer", em 7 orações, "tomar", em 2 orações, e "beber", em 7 orações, sendo este último o único verbo de consumo que não apareceu associado ao se aspectual em nenhuma sentença.

No que diz respeito aos tipos de verbo produzidos pelos cinco falantes nativos do espanhol do Chile, baseado na classificação de Vendler (1967), foram produzidos, associados ao operador aspectual se, verbos de processo culminado (verbos durativos com um ponto final delimitado) - "comer", "tomar", "exprimir" (espremer) e "partir" - e um verbo de culminação (verbo pontual) - "acabar". O gráfico 2 a seguir apresenta os diferentes tipos de verbo nas sentenças télicas com e sem o operador aspectual se produzidos por todos os informantes nesse teste.

\footnotetext{
${ }^{16}$ Nos parágrafos que seguem a exibição dos gráficos inseridos neste artigo, optamos por dar destaque aos números (absolutos e percentuais) mais relevantes para os resultados obtidos e análises propostas.
} 
Gráfico 2: Tipos de verbos utilizados na produção de sentenças télicas do teste de produção semiespontânea.

Teste de produção semiespontânea: Tipos de verbo

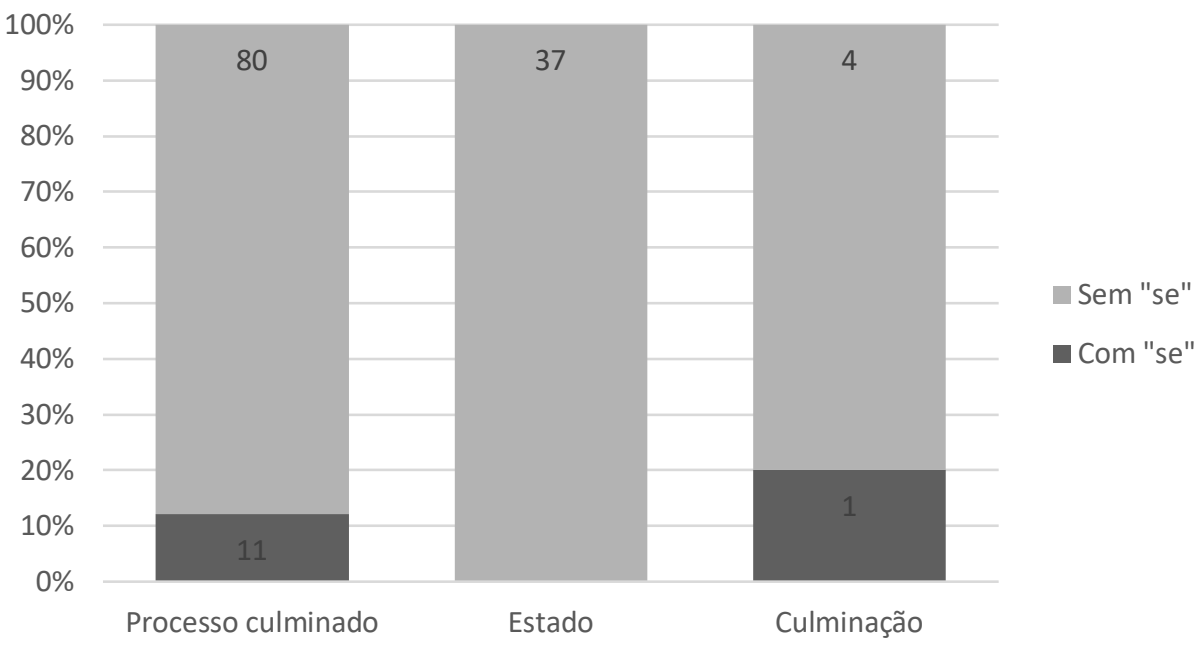

O gráfico 2 demonstra que os verbos de processo culminado foram combinados ao se aspectual em 12,1\% das ocorrências deste tipo de verbo, os verbos de estado não foram combinados ao se aspectual e os verbos de culminação foram combinados ao se aspectual em $20 \%$ das ocorrências deste tipo de verbo.

O gráfico 2 indica ainda que houve 1 locorrências de verbos de processo culminado associados ao operador aspectual se, sendo que 9 delas foram com verbos de processo culminado que eram também classificados como verbos de consumo (sendo as 2 outras ocorrências com os verbos "exprimir" (espremer) e "partir"). Logo, é possível especular que a motivação para o uso dessa partícula com os verbos de processo culminado tenha sido especialmente a sua natureza semântica (verbo de consumo) e não a sua natureza semântica-aspectual (verbo de processo culminado).

Ainda a respeito dos resultados apresentados no gráfico 2, é importante destacar que os verbos de culminação utilizados no teste não associados ao se aspectual foram "abrir", "poner" (pôr) e "meter" e o único verbo de culminação produzido associado a esse operador foi o verbo "acabar", que é caracterizado como um verbo inacusativo.

No que diz respeito a verbos inacusativos, segundo Montrul (1999), há uma variação chamada de alternância causativa/incoativa. Nessa alternância, há sempre uma mudança de estado envolvida e a forma transitiva do verbo caracteriza a parte causativa - exemplo em (27) - e a forma inacusativa do verbo caracteriza a parte incoativa - exemplo em (28).

\section{(27) El cocinero derritió la manteca.}

'O menino derreteu a manteiga.'

(28) La manteca se derritió.

'A manteiga derreteu. ${ }^{17}$

De acordo com Montrul (1999), a forma transitiva do verbo está diretamente ligada à forma inacusativa, já que a parte transitiva possui um significado causativo que está relacionado à parte inacusativa. Além disso, em espanhol, na sentença com o verbo caracterizando a parte incoativa, há a presença obrigatória da partícula se (MONTRUL, 1999; LAWALL, 2012), como mostra a sentença em (28). Tal partícula é conhecida na literatura como se incoativo.

${ }^{17}$ Os exemplos em (27) e (28) foram retirados de Montrul (1999, p. 194). 
Em relação ao verbo "acabar", é possível interpretar que esse verbo faça parte da alternância causativa/ incoativa e a partícula se presente na sentença em (15) seria um se incoativo ao invés do operador aspectual se como o dos demais exemplos. É possível propor que o verbo "acabar" faça parte dessa alternância uma vez que, além da sentença em (15), é possível pensar em uma sentença como a do exemplo em (29) a seguir.

(29) El chico acabó (con) la bebida.

'O menino acabou com a bebida'.

Sendo assim, o exemplo em (29) constituiria a parte causativa e o exemplo em (15), a parte incoativa. No entanto, mesmo com a possibilidade de a partícula se presente na sentença em (15) ser um se incoativo ao invés do operador aspectual se, optamos por considerá-lo na análise por dois motivos: o primeiro motivo é que, segundo Nishida (1994), o verbo "acabar" é inerentemente télico, pois produz situações télicas quando possuem um sintagma nominal determinado como objeto direto; e o segundo motivo é que, segundo Montrul (1999), o se incoativo também está associado a uma propriedade aspectual, uma vez que denota telicidade.

Com base na análise feita anteriormente a respeito do verbo "acabar", o único verbo de culminação associado à partícula se no teste de produção semiespontânea, especulamos que, provavelmente, a motivação para a sua associação à partícula se foi o fato de este ser um verbo inacusativo que atua na alternância causativa/incoativa sendo utilizado em sua parte incoativa, e não a sua natureza semântica-aspectual (verbo de culminação).

Em relação à morfologia, houve associação do operador aspectual se às morfologias de pretérito perfeito simples, de infinitivo e uma única ocorrência com o verbo "estar" no presente seguido do verbo principal no gerúndio. O gráfico 3 a seguir mostra as morfologias utilizadas nas sentenças télicas com e sem o operador aspectual se produzidas por todos os informantes nesse teste.

Gráfico 3: Morfologias utilizadas na produção de sentenças télicas do teste de produção semiespontânea.

Teste de produção semiespontânea: Morfologias

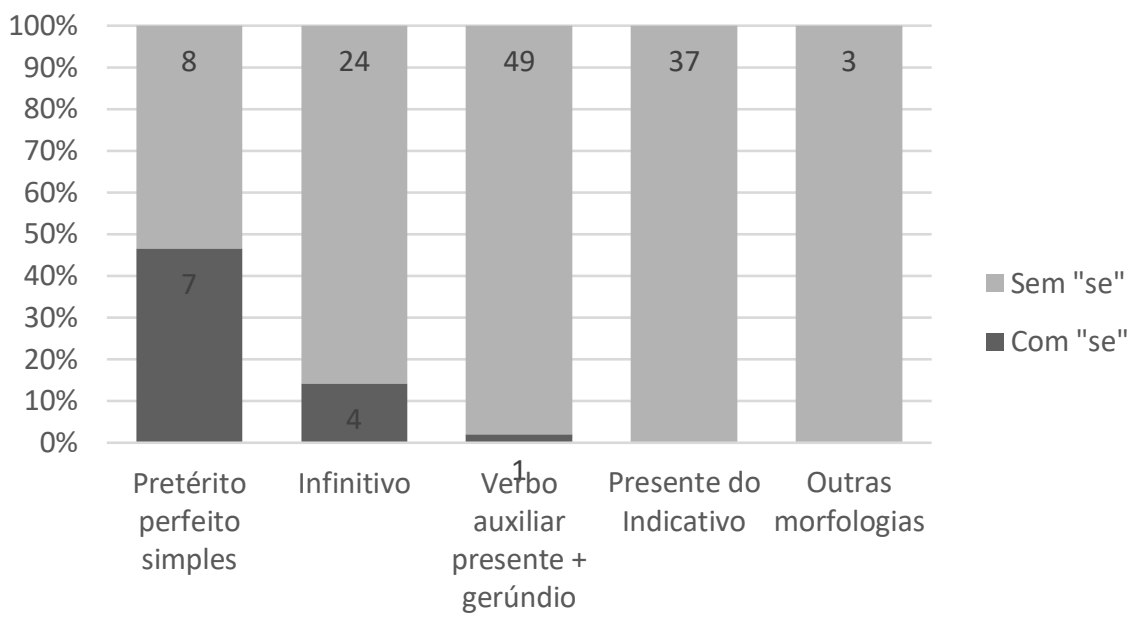

Como indica o gráfico 3, além das morfologias citadas anteriormente que apareceram combinadas ao operador aspectual se, houve ainda produção de sentenças télicas sem o se aspectual sobretudo com a morfologia de presente do Indicativo. A morfologia de pretérito perfeito simples foi a que se mostrou com uma menor diferença entre o número de sentenças com e aquelas sem o se aspectual - 46,7\% com a partícula se contra 53,3\% sem essa partícula.

Ainda a respeito dos dados resumidos no gráfico 3, vale destacar que a única ocorrência do se aspectual associada ao verbo auxiliar no presente seguido do verbo principal no gerúndio, o que constituiu apenas $2 \%$ de ocorrência da partícula associada a essa perífrase

Lourençoni \& Martins | O operador aspectual se no espanholdo Chile: contextos.. 
verbal, foi observada na oração apresentada em (22) ("en la segunda foto la señora se está exprimiendo los limones."). Tal ocorrência possibilitou a refutação da hipótese (ii) deste artigo - segundo a qual o operador aspectual se não aparece combinado ao verbo "estar" no presente seguido de um verbo principal no gerúndio no espanhol do Chile -, análise a serretomada nas considerações finais deste artigo.

Por fim, cabe destacar que o resultado apresentado no gráfico 3 sugere que a partícula se talvez seja mais produtiva com a morfologia de passado perfectivo.

\subsection{TESTE DE JULGAMENTO DE GRAMATICALIDADE COMENTADO}

Como mencionado na descrição do teste de julgamento de gramaticalidade comentado na seção de metodologia, era dito ao informante que ele poderia alterar qualquer constituinte presente na sentença que julgasse como estranha, não estando restrita a possibilidade de modificação a nenhum constituinte específico, como, por exemplo, à morfologia verbal ou à presença/ausência do operador aspectual se.

Em relação ao se aspectual, havia sentenças com e sem a sua presença. Ao recriar a sentença para torná-la mais natural, os informantes poderiam manter o se aspectual em uma sentença na qual ele estivesse presente, retirar o se aspectual em uma sentença na qual ele estivesse presente ou inserir o se aspectual em uma sentença na qual ele não estivesse presente.

Se as alterações feitas pelo informante nas sentenças alterassem a sua telicidade, tornando-as atélicas, essas eram excluídas da análise. Com isso, duas sentenças do teste foram excluídas, de modo que consideramos na análise um total de cento e dezoito sentenças, somando-se as sentenças julgadas e comentadas pelos cinco informantes.

Além disso, se as alterações feitas pelo informante nas sentenças incidissem em uma das variáveis do teste - o tipo de verbo e a morfologia verbal -, essas alterações eram consideradas na análise. Por exemplo, se o informante julgasse uma sentença que apresentasse a morfologia de pretérito perfeito simples como estranha e, no momento de modificá-la, alterasse a morfologia para o pretérito perfeito composto, na análise seria contabilizada uma sentença com a morfologia de pretérito perfeito composto e não de pretérito perfeito simples. O mesmo critério para a análise se aplica ao tipo de verbo utilizado na sentença, sendo considerado para a análise o tipo de verbo utilizado efetivamente pelo informante na alteração da sentença, e não o tipo de verbo originalmente incluído na concepção do teste.

Devido ao critério exposto acima, além dos doze verbos selecionados para o teste, outros verbos apareceram após as alterações feitas pelos informantes nas sentenças. Os verbos que apareceram combinados ao operador aspectual se nas sentenças consideradas como naturais ou alteradas para que se tornassem naturais pelos informantes foram "acabar", "aprender", "comer", "caer" (cair), "rallar" (ralar), "terminar" e "tomar". Desses verbos, "aprender" e "terminar" não estavam relacionados dentre os doze verbos selecionados para o teste e apareceram devido às mudanças feitas pelos falantes em determinadas sentenças.

Dos sete verbos citados acima que apareceram combinados ao operador aspectual se, assim como no teste de produção semiespontânea, apenas "comer" e "tomar" podem ser caracterizados como verbos de consumo. O gráfico 4 a seguir apresenta os verbos de consumo em oposição aos demais verbos nas sentenças télicas com e sem o operador aspectual se produzidos por todos os informantes nesse teste. No gráfico 4 a seguir, bem como nos demais gráficos apresentados nesta seção, as sentenças com o se aspectual referem-se tanto àquelas em que o se foi mantido nas sentenças nas quais ele estava presente quanto àquelas em que ele foi inserido nas sentenças nas quais ele estava ausente; enquanto as sentenças sem o se aspectual referem-se tanto àquelas em que o se foi retirado das sentenças nas quais ele estava presente quanto àquelas em que o se não foi incluído nas sentenças nas quais ele estava ausente. 
Gráfico 4: Verbos de consumo versus demais verbos presentes nas sentenças télicas do teste de julgamento de gramaticalidade comentado.

Teste de julgamento comentado: verbos de consumo versus demais verbos

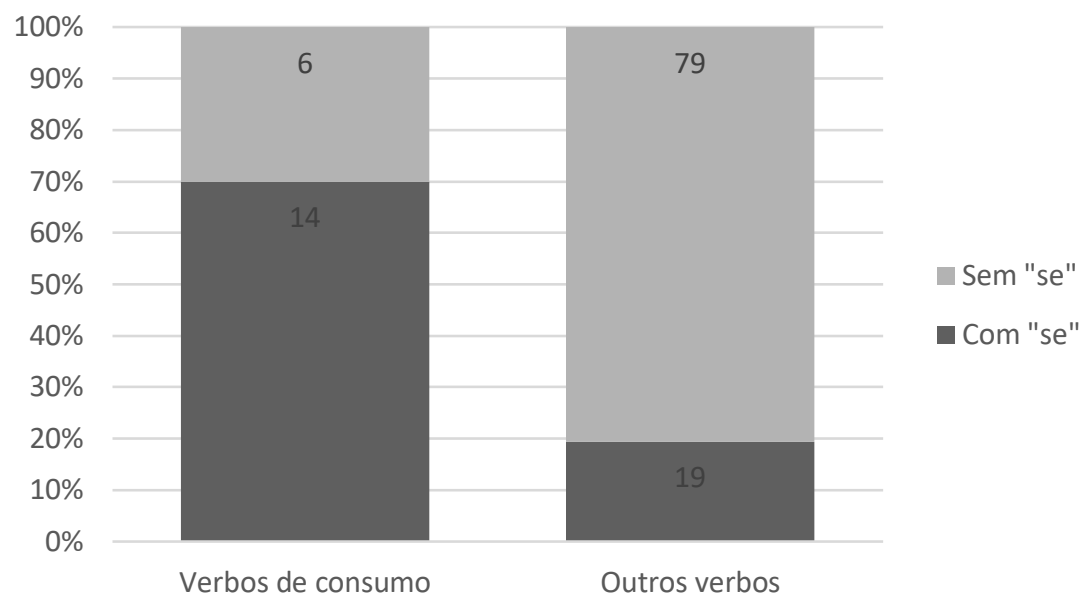

O gráfico 4 demonstra que verbos de consumo foram combinados ao operador aspectual se em 14 ocorrências, o que corresponde a 70\% das produções destes verbos. Já os verbos que não eram de consumo foram combinados ao operador aspectual se em 19 ocorrências, o que corresponde a 19,4\% das produções destes verbos. Tal quadro corrobora o que já havia sido sugerido pela análise dos verbos de consumo em oposição aos demais verbos nos resultados do teste de produção semiespontânea, apresentado na subseção anterior: a ocorrência do se aspectual parece ser bem mais produtiva com verbos de consumo.

A análise da variável tipo de verbo, controlada no teste, revelou que, baseado na classificação de Vendler (1957), apareceram, associados ao operador aspectual se, verbos de processo culminado (verbos durativos com um ponto final delimitado) - "comer", "rallar" (ralar) e "tomar" -, um verbo de estado (verbo não dinâmico) - "aprender" - e verbos de culminação (verbos pontuais) "acabar", "caer" (cair) e "terminar". O gráfico 5 a seguir mostra os tipos de verbos utilizados em todas as sentenças télicas com e sem o operador aspectual se produzidos por todos os informantes nesse teste.

Gráfico 5: Tipos de verbo presentes nas sentenças télicas do teste de julgamento de gramaticalidade comentado

Teste de julgamento comentado: Tipos de verbos

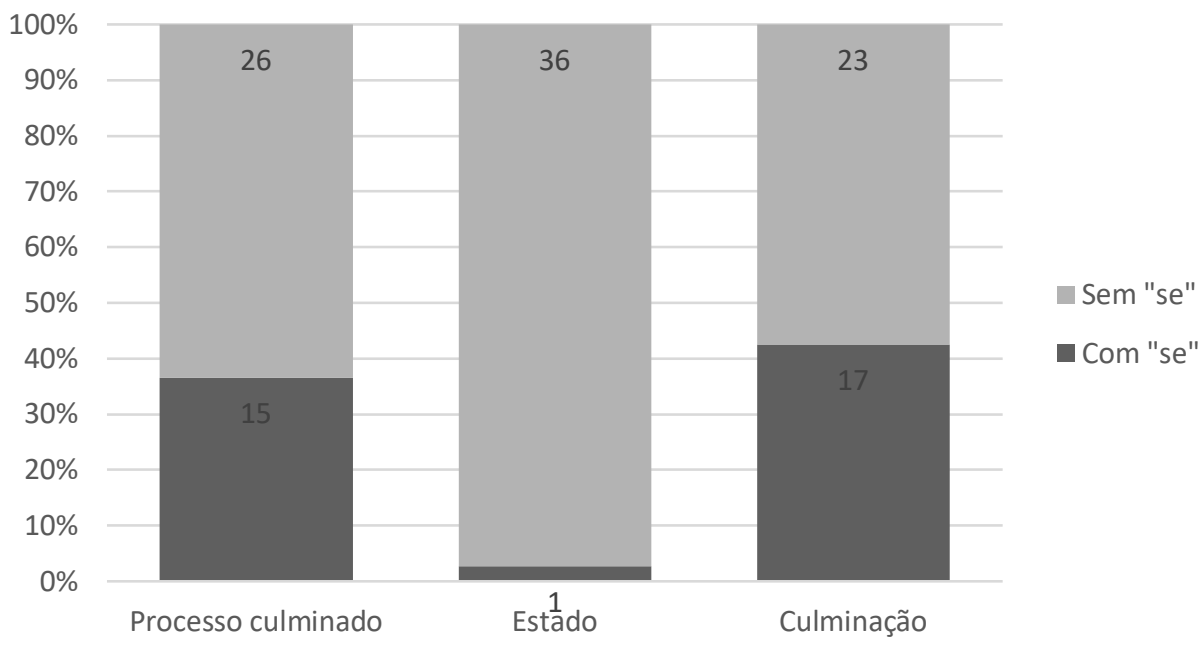


O gráfico 5 demonstra que os verbos de processo culminado foram combinados ao se aspectual em 36,6\% das ocorrências deste tipo de verbo, os verbos de estado, em somente $2,7 \%$ das ocorrências deste tipo de verbo e os verbos de culminação, em 42,5\% das ocorrências deste tipo de verbo.

Como observamos a partir da análise dos tipos de verbos em sentenças télicas do teste de produção semiespontânea, quase a totalidade dos verbos de processo culminado associados ao se aspectual era caracterizada como verbos de consumo (apenas uma ocorrência, com o verbo "rallar" (ralar), não o era), de modo que, provavelmente, a motivação para o uso da partícula se com esses verbos foi especialmente a sua natureza semântica (verbo de consumo) e não a sua natureza semântica-aspectual (verbo de processo culminado).

Como também destacado por meio do gráfico 5, houve somente uma ocorrência de verbo de estado com o se aspectual, apresentada na oração entre colchetes do exemplo em (30) a seguir.

\section{(30) "Miguel estudió mucho y [se aprendió todo el contenido]"18}

'Miguel estudou muito e aprendeu todo o conteúdo.'

O fato de o verbo "aprender" ter sido o único verbo de estado no qual foi utilizado o operador aspectual se vai na direção do que foi proposto por De Miguel e Lagunilla (2000), apresentado por meio do exemplo (9) ("Me sé la lección") na seção 2 deste artigo, já que esse, assim como o verbo "saber" do exemplo mencionado, é um verbo estativo que envolve uma mudança de estado, ou seja, entende-se da sentença em (30), acima, que Miguel "passa a conhecer" o conteúdo estudado mediante o que é expresso pelo verbo "aprender". Talvez, de fato, apenas verbos de estado dessa natureza autorizem a produção do se aspectual no espanhol do Chile.

Ainda com relação aos tipos de verbo utilizados, tratado no gráfico 5 , notamos que os três verbos de culminação associados à partícula se, "acabar", "caer" (cair) e "terminar", eram verbos inacusativos, o que levou à especulação, tal como feito na análise dos resultados do teste de produção semiespontânea, de que não era a natureza semântica-aspectual do verbo - verbos de culminação (pontuais) - que levava à produção de tal partícula, e sim a sua natureza sintática - verbos inacusativos.

Por essa razão, optamos por contabilizar também quando os verbos apareciam em contexto inacusativo e quando os verbos apareciam em contexto transitivo. O gráfico 6 a seguir mostra os verbos inacusativos e transitivos em todas as sentenças télicas com e sem o operador aspectual se produzidos por todos os informantes nesse teste.

Gráfico 6: Verbos inacusativos e transitivos presentes nas sentenças télicas do teste de julgamento de gramaticalidade comentado.

Teste de julgamento comentado: Verbos e sua seleção

argumental

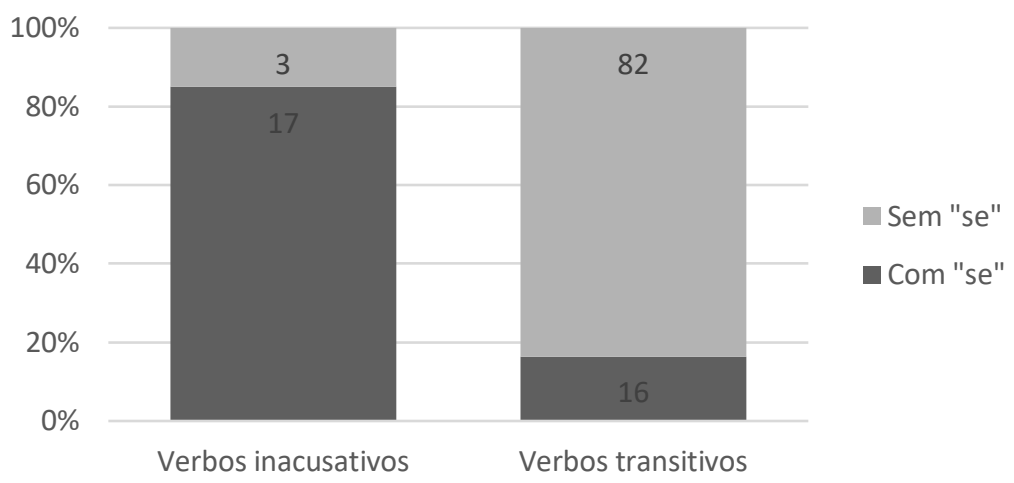

\footnotetext{
${ }^{18}$ Analisamos o verbo "aprender" como um verbo de estado inspiradas em Garcia (2004), que propõe uma classificação semântica dos verbos do português. Segundo o autor, "aprender" é um exemplo de um subtipo dos "verbos relacionais", ou seja, "verbos que não podem funcionar como resposta a perguntas com os "pró-verbos" fazer e acontecer, visto servirem mais para indicar o tipo de relação que se estabelece entre os elementos do seu domínio [...] do que para indicar o que ocorre com tais elementos" (GARCIA, 2004, p. 52, grifo do autor). Logo, entendemos que esse verbo possui as características típicas do chamado "verbo de estado".
} 
O gráfico 6 acima mostra que os verbos inacusativos - todos verbos de culminação, como apresentado anteriormente - foram combinados ao se aspectual em $85 \%$ das ocorrências destes verbos e os verbos transitivos, em 16,3\% das ocorrências destes verbos.

Em relação aos verbos inacusativos, como foi abordado na subseção anterior, "acabar" parece fazer parte da alternância causativa/incoativa e o mesmo parece se aplicar ao verbo "terminar", uma vez que é possível dizer que "alguém terminou a bebida" e também que "a bebida terminou". Já o verbo "caer" (cair) não parece fazer parte dessa alternância por, apesar de ser possível falar "a prateleira caiu", não ser possível falar que "^alguém caiu a prateleira".

Talvez por essa razão, as três ocorrências de verbos inacusativos que apareceram sem a partícula se foram com o verbo "caer" (cair), que não faz parte da alternância causativa/incoativa. Os demais verbos inacusativos, "acabar" e "terminar", que fazem parte da alternância causativa/incoativa, apareceram sempre associados à partícula se, corroborando, assim, o que a literatura aborda sobre a obrigatoriedade da partícula se na parte incoativa dessa alternância (MONTRUL, 1999; LAWALL, 2012).

Como mencionado na segunda seção deste artigo, de acordo com De Miguel (1999), em sentenças com verbos inacusativos, a presença do operador aspectual se só é possível se houver menção implícita ou explícita ao limite inicial do evento. Das ocorrências com verbos inacusativos associados ao se aspectual que apareceram no teste, aquelas com o verbo "caer" (cair), como em "El plato se cayó de la mesa", parecem apresentar uma menção explícita ao ponto inicial do evento. As outras ocorrências com verbos inacusativos associados ao se aspectual, aquelas com os verbos "acabar" e "terminar", de maneira contrária, parecem apresentar uma menção explícita ao final do evento. No entanto, apesar de estes verbos destacarem especialmente o fim do evento, o seu início fica subentendido e talvez isso possa ser considerado a menção implícita ao início do evento a qual De Miguel (1999) faz referência. Seguindo tal interpretação, os dados obtidos neste estudo acerca da combinação do se aspectual a verbos inacusativos no espanhol do Chile confirmariam a proposição da autora segundo a qual tal combinação só é autorizada quando nestas sentenças há menção implícita ou explícita ao ponto inicial do evento.

A análise da variável morfologia verbal, controlada no teste, revelou que houve associação do operador aspectual se às morfologias de pretérito perfeito simples, de pretérito perfeito composto, de imperfeito do Subjuntivo e de presente do Subjuntivo. O gráfico 7 a seguir apresenta as morfologias utilizadas em todas as sentenças télicas com e sem o operador aspectual se produzidas por todos os informantes nesse teste.

Gráfico 7: Morfologias presentes nas sentenças télicas do teste de julgamento de gramaticalidade comentado.

Teste de julgamento comentado: Morfologias

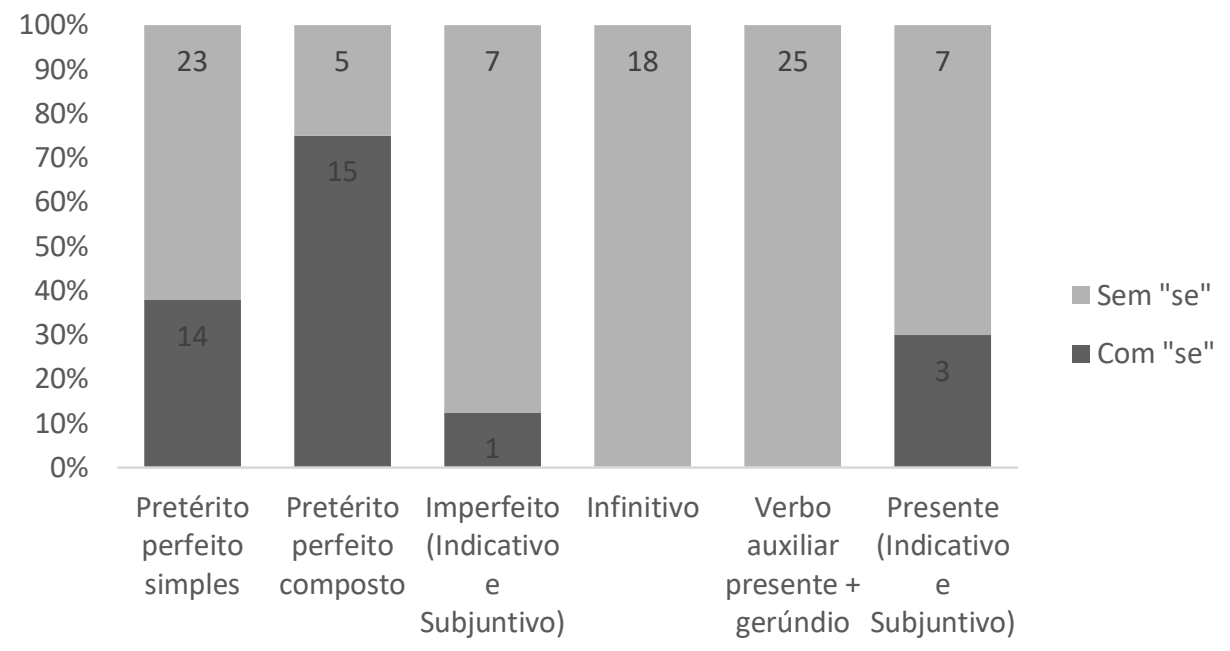


O gráfico 7 mostra que, além das quatro morfologias selecionadas para o teste - pretérito perfeito simples, pretérito perfeito composto, infinitivo e verbo "estar" no presente seguido de um verbo principal no gerúndio -, apareceram também sentenças télicas com as morfologias de presente do Indicativo e do Subjuntivo e de imperfeito do Indicativo e do Subjuntivo. A morfologia de pretérito perfeito composto foi a que se mostrou em maior número associada ao operador aspectual se - 75\% das sentenças com essa morfologia associadas a esse operador.A segunda morfologia mais amplamente associada ao operador aspectual se foi a de pretérito perfeito simples - 37,8\% das sentenças com essa morfologia associadas ao se aspectual.

Como também sugerido pela análise da morfologia verbal a partir dos resultados obtidos no teste de produção semiespontânea, os dados apresentados no gráfico 7 mostram que o se aspectual parece ser mais produtivo com a morfologia de passado perfectivo, já que tanto pretérito perfeito simples - morfologia associada ao se aspectual nos dois testes - quanto o pretérito perfeito composto morfologia amplamente associada ao se aspectual no segundo teste - referem-se ao tempo passado e ao aspecto perfectivo.

\section{CONSIDERAÇÕES FINAIS}

Uma vez que parece haver na literatura informações divergentes sobre o uso do operador aspectual se, este artigo tinha por objetivo investigar contextos semânticos e morfossintáticos que ensejassem o uso do operador aspectual se na expressão do traço aspectual de telicidade no espanhol do Chile. Para alcançar tal objetivo, aplicamos um teste de produção semiespontânea -desenvolvido por Martins, Lourençoni e Novaes (2013) - e um teste de julgamento de gramaticalidade comentado a cinco falantes nativos do espanhol do Chile.

Para investigar um contexto semântico que poderia ensejar o uso do se aspectual, investigamos a sua associação aos verbos de consumo - verbos cuja semântica aponta para uma aquisição ou incorporação do objeto sobre o qual recai a ação do verbo (CASTRO; MORENO, 2006; GARCÍA; PASCUAL, 2012) -em oposição aos demais verbos. Tal análise revelou que o se aspectual foi associado aos dois tipos de verbos nos dois testes. Os dois parágrafos a seguir resumem os principais resultados encontrados quanto à associação do se aspectual a esses dois tipos de verbos.

Quanto aos verbos de consumo, observamos que os dois únicos verbos desse tipo associados ao se aspectual produzidos pelos informantes em ambos os testes foram "comer" e "tomar", sendo ambos também produzidos desassociados do se aspectual em sentenças télicas nos dois testes. O único verbo de consumo que também apareceu nas sentenças télicas - mais especificamente, em sete ocorrências no teste de produção semiespontânea -, sendo este sempre desassociado do se aspectual, foi o verbo "beber". Mais estudos acerca da semântica aspectual de "beber" em oposição a "tomar" necessitam ser realizados para explicar a motivação da produção do operador aspectual com o segundo, mas não com o primeiro destes verbos. Ainda a respeito de verbos de consumo, destacamos o fato de que, embora diferentes tipos de verbo tenham sido combinados ao se aspectual, a associação dessa partícula especificamente aos verbos de consumo mostrou-se bastante produtiva no espanhol do Chile. Assim, avaliamos que a análise dos resultados considerando-se a associação do se aspectual a verbos de consumo em contraposição à sua associação aos demais verbos mostrou-se relevante também por possibilitar a constatação de que essa partícula é mais produtiva com verbos de consumo do que com outros tipos de verbo no espanhol do Chile.

Ainda a respeito dos tipos semânticos de verbos com os quais o se aspectual foi combinado, quanto aos verbos de outras naturezas semânticas que não de consumo, observamos nos dois testes o operador aspectual se combinado aos verbos "exprimir" (espremer), "partir", "aprender", "rallar" (ralar), "caer" (cair), "acabar" e "terminar", sendo esses três últimos considerados verbos inacusativos.

Logo, com base nos resultados resumidos nos três parágrafos acima, podemos dizer que a hipótese (i) deste trabalho, segundo a qual o operador aspectual se aparece exclusivamente combinado a verbos de consumo no espanhol do Chile (BABCOCK, 1970 apud LÓPEZ, 2002; SCHROTEN, 1972 apudLÓPEZ, 2002), foi refutada.

Para investigar um contexto semântico-aspectual que poderia ensejar o uso do se aspectual, optamos por analisar as sentenças télicas produzidas com e sem a presença do operador aspectual se levando em consideração o tipo de verbo segundo a classificação de 
Vendler (1967) presente nas sentenças. No que diz respeito a essa variável, observamos que o se aspectual apareceu associado a verbos de processo culminado e a verbos de culminação, nos dois testes, e a um único verbo de estado, no teste de julgamento de gramaticalidade comentado. As conclusões a respeito da análise dessa variável estão sistematizadas nos três parágrafos a seguir.

Quanto aos verbos de processo culminado, destacamos que quase a totalidade desses verbos eram verbos de consumo, o que possibilitou a interpretação de que a principal motivação para o uso da partícula se associada a esses verbos foi a sua natureza semântica (verbo de consumo) e não a sua natureza semântica-aspectual (verbo de processo culminado).

No que diz respeito aos verbos de culminação, observamos que todos os verbos dessa natureza associados à partícula se, nos dois testes, eram verbos inacusativos, sendo a sua maioria a parte incoativa da alternância causativa/incoativa, como foi o caso dos verbos "acabar" e "terminar". Por conta dessa percepção, realizamos, com base nos resultados do teste de julgamento de gramaticalidade comentado, uma comparação entre os verbos inacusativos e transitivos com e sem a partícula se. Tal análise possibilitou a observação não só de que os verbos inacusativos se associam mais à partícula se do que os verbos transitivos como de que todos os verbos inacusativos que participam da alternância causativa/incoativa presentes nos dados foram associados à partícula se quando utilizados em sua parte incoativa- neste caso, também chamado de se incoativo. Logo, os dados deste artigo tanto corroboram a proposta de que este se aspectual - o se incoativo - é obrigatório no espanhol do Chile, em consonância com outros estudos do espanhol a esse respeito (MONTRUL, 1999; LAWALL, 2012), quanto possibilitam a interpretação de que o fator preponderante para a utilização do se aspectual com verbos de culminação não foi seu tipo semântico-aspectual e sim a natureza sintática desses verbos, ou seja, o fato de serem inacusativos.

No que tange ao único verbo de estado utilizado com o se aspectual, destacamos que há na literatura uma informação divergente no que diz respeito à combinação do operador aspectual se com verbos de estado. Por um lado, Sanz e Laka (2002) e Suárez Cepeda (2005) afirmam que verbos de estado genuínos não podem se associar ao se aspectual. Por outro lado, Nishida (1994) afirma que tais verbos podem aparecer combinados a essa partícula e De Miguel e Lagunilla (2000) apontam que verbos de estado que indicam mudança de estado, como "saber" em "Me sé la lección", autorizam a produção dessa partícula. Neste trabalho, os resultados dos testes mostraram associação do operador aspectual se a um único verbo de estado que indica mudança de estado ("Miguel estudió mucho y se aprendió todo el contenido"). Logo, talvez esse seja, de fato, o único tipo de verbo de estado que autoriza essa partícula no espanhol do Chile, o que necessita de mais investigações.

Por fim, para investigar um contexto morfossintático que poderia ensejar o uso do se aspectual, optamos por analisar as sentenças télicas produzidas com e sem a presença do operador aspectual se levando em consideração a morfologia verbal presente nas sentenças. No que diz respeito a essa variável, observamos que o se aspectual foi associado às morfologias de pretérito perfeito simples, nos dois testes, de infinitivo e a um verbo "estar" no presente seguido de um verbo principal no gerúndio, no teste de produção semiespontânea, e de pretérito perfeito composto, de presente do Subjuntivo e de imperfeito do Subjuntivo, no teste de julgamento de gramaticalidade comentado. As conclusões a respeito da análise dessa variável estão sistematizadas nos dois parágrafos a seguir.

É importante ressaltar que, em ambos os testes, a morfologia de pretérito perfeito simples foi a que se mostrou com uma menor diferença entre o número de sentenças sem e aquele com o se aspectual. Além disso, no teste de julgamento de gramaticalidade comentado, a morfologia de pretérito perfeito composto apareceu em maior número associada ao operador aspectual $s e$. Tais dados mostram que a partícula se parece ser mais produtiva com a morfologia de passado perfectivo, sugerindo que, embora essa partícula possa ser usada também em sentenças télicas nas quais o ponto final da ação ainda não foi alcançado, talvez o seu uso seja preferido nos casos em que ele tenha sido alcançado, indo na direção - ainda que relativizando essa proposição - do que propõem De Miguel e Lagunilla (2000), López (2002), Suárez Cepeda (2005) e Preuss e Finger (2009), que afirmam que o se aspectual ocorre em sentenças télicas nas quais o ponto final da ação tenha sido atingido.

Conforme dito anteriormente, houve uma única ocorrência do operador aspectual se associado ao "estar" no presente seguido de um verbo principal no gerúndio e tal fato merece algumas considerações. Primeiramente, fazemos a consideração de que esse dado parece contrariar a ideia de que a presença do operador aspectual se na sentença necessariamente indique uma leitura de ponto final

Lourençoni \& Martins O operador aspectual se no espanhol do Chile: contextos... 
da ação alcançado, conforme defendido por De Miguel e Lagunilla (2000), López (2002), Suárez Cepeda (2005), Preuss e Finger (2009), entre outros. No entanto, cabe ainda a consideração de que, conforme anunciado na introdução deste artigo, este estudo enquadra-se no paradigma teórico da gramática gerativa e, de acordo com essa teoria, a faculdade da linguagem dá conta de um conhecimento mental particular, de modo que é possível especular que o fato de o se aspectual não ser exclusivamente associado a ações que tenham alcançado o seu ponto final talvez não seja parte do conhecimento linguístico comum a qualquer falante nativo do espanhol do Chile, sendo, nesse caso, parte do conhecimento linguístico especificamente do falante que utilizou a sentença "en la segunda foto la señora se está exprimiendo los limones." Apesar disso, fazemos, por fim, a consideração de que, segundo a tradição da "lógica da pesquisa científica" de Popper (2007), basta a observação de uma única ocorrência que contrarie a hipótese de pesquisa nos dados para que esta seja refutada.

Logo, com base na discussão feita no parágrafo precedente, a hipótese (ii) testada neste artigo, segundo a qual o operador aspectual se não aparece combinado ao verbo "estar" no presente seguido de um verbo principal no gerúndio no espanhol do Chile (DE MIGUEL; LAGUNILLA, 2000; LÓPEZ, 2002; SUÁREZ CEPEDA, 2005; PREUSS; FINGER, 2009), foi refutada.

\section{REFERÊNCIAS}

ALCINA, Juan; BLECUA, José Manuel. Gramática española. 10.ed. Barcelona: Editorial Ariel, S.A., 1998. p. 915.

CASTRO, Alejandro Castañeda; MORENO, Elisabeth Melguizo. Querían dormirlo, se ha dormido, está durmiendo. Gramática cognitiva para la presentación de los usos del se en clase de ELE. Mosaico: Revista para la promoción y apoyo a la enseñanza del español, Bruxelas, n. 18, p. 13-20, 2006.

DE MIGUEL, Elena. El aspecto léxico. In: BOSQUE, Ignacio; DEMONTE, Violeta (Dir.). Gramática descriptiva de la Lengua Española. Volumen 2: Las construcciones sintácticas fundamentales; relaciones temporales, aspectuales y modales. Madrid: Espasa Calpe, S.A, 1999.p. 2977-3060.

DE MIGUEL, Elena; LAGUNILLA, Marina Fernández. El Operador Aspectual SE. Revista Española de Linguística, Madrid, v. 30, n. 1, p. 13-43, 2000.

GARCIA, Afrânio da Silva. Uma tipologia semântica do verbo no português.Revista Soletras, Rio de Janeiro, n. 8, p. 52-70, 2004.

GARCÍA, Ismael Iván Teomiro; PASCUAL, Cristina Romero. Theta Meets Aspect: The Spanish Aspectual "Se" with Consumption Verbs.Topics in Linguistics, issue 10- Approaches to Text and Discourse Analysis,Nitra, p. 20-27, dez. 2012.

LAWALL, Raquel Fellet. A alternância causativa/incoativa em espanhol como L1 e L2. Revista Virtual de Estudos da Linguagem ReVEL,Porto Alegre, v. 10, n. 18, p. 1-27, 2012.

LÓPEZ, Cristina Sánchez. Las construcciones con se. Estado de la cuestión. In: (Ed.).Las construcciones con se. Madrid: Visor, 2002.p. 13-163.

MARTINS, Adriana; LOURENÇONI, Débora; NOVAES, Celso. A expressão de traços aspectuais em diferentes constituintes da oração no português do Brasil. Revista FSA,Teresina, v. 10, n. 4, p. 260-289, 2013. 
MONTRUL, Silvina. Causative Errors with Unaccustaive Verbs in L2 Spanish. Second Language Research,Londres, v. 15, n. 2, p. 191-219, 1999.

NISHIDA, Chiyo. The Spanish Reflexive Clitic se as an Aspectual Class Marker. Linguistics,Berlim, v. 32, p. 425-458, 1994.

POPPER, Karl. A lógica da pesquisa científica. Tradução de Leonidas Hegenberg e Octanny Silveira da Mota. São Paulo: Cultrix, 2007.

PREUSS, Elena Ortiz; FINGER, Ingrid. O papel da instrução na aquisição do Espanhol como L2: um estudo sobre o se - operador aspectual como delimitador. Linguagem \& Ensino, Pelotas, v. 12, n. 2, p. 435-462, 2009.

RAE - Real Academia Española y Asociación de Academias de la Lengua Española. Nueva gramática de la lengua española. Manual. Madrid: Espasa, 2010.

ROTHSTEIN, Susan. What are incremental themes? ZAS Papers in Linguistics, Berlim, v. 22, p. 139-157,2001.

SANZ, Montserrat; LAKA, Itziar. Oraciones transitivas con se: el modo de acción en la sintaxis. In: LÓPEZ, Cristina Sánchez (Ed.). Las construcciones con se. Madrid: Visor, 2002.p. 309-338.

SUÁREZ CEPEDA, Sonia.Pedro comió la torta vs. Pedro se comió la torta: L2 Acquisition of Spanish Telic se constructions.Anuario de la Facultad de Ciencias Humanas- UNLPam, Santa Rosa, año VII, n. 7, p. 277-295, 2005.

VENDLER, Zeno. Verbs and times. In: (Ed.). Linguistics in Philosophy. Ithaca: Cornell University Press, 1967. p. 97-121. 